\title{
Five Effective Ways To Support At-Risk And Wounded Students In Thriving At Alternative High Schools And Earning Their Diplomas!
}

\author{
Tammy Williams, Principal, Prince George's County Public Schools, MD, USA
}

\begin{abstract}
Effective alternative high schools service the whole child - academically, socially, emotionally, and developmentally. It is critical to address the needs of the child through wrap-around support services that include Building Positive Relationships, Providing Supportive Safety Nets at School, Offering Counseling Services, Having a Food and Toiletry Pantry, Laundry Service and Bus Pass Bank and Focusing on Post-secondary Plans. A clear focus on these five wrap-around support areas will assist at-risk and wounded students to earn their high school diplomas - and level the students' playing fields with an emphasis on building productive futures in college, military and/or career.
\end{abstract}

Keywords: At-Risk Students, Wounded Students, Alternative High Schools, Wrap-Around Support Services, High School Diplomas

\section{INTRODUCTION}

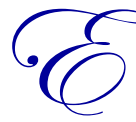
ffective alternative high schools are vital to reaching and meeting the needs of at-risk or wounded students developmentally, academically, and socially (McPartland \& Nettles, 1991; Slavin \& Madden, 2004). They provide opportunities for a unique population of students who do not find success in traditional schools. While society may not often hear of the great success stories, despite numerous challenges, and often against all odds, there are alternative high schools where students are achieving substantial success based on the school's strategic efforts to build and maintain positive relationships and high expectations for students to succeed and earn their high school diplomas.

Nationally, students who traditionally attend alternative high schools typically are described as at-risk or wounded students who, by their circumstances, are statistically more likely than others to fail academically or who are beyond the point of "at-risk" and "suffers from hopelessness," respectively. Those determining the criteria of at-risk status often focus on students who are ethnic minorities, academically disadvantaged, disabled, characterized by low socioeconomic status, experienced trauma, or on a probationary condition over past behavioral issues (Anderson-Moore, 2006). Moreover, at-risk students typically have at least one or more of the following characteristics: retention in grade level, poor attendance, behavioral problems, low socioeconomic status or poverty, unsatisfactory achievement, substance abuse, or teenage pregnancy (Slavin \& Madden, 2004). Wounded students deal with circumstances such as withholdings in childhood, aggression during early development, stressful events, parental betrayals and longterm constraints that set the typology for at-risk and wounded students (Hendershot, 2008). At-risk students have significantly higher rates of dropping out of school. According to StatisticsBrain.com (2014), 8,300 students drop out of high school each day; that is 3,030,000 students annually, with the bulk of these students (36\%) dropping out in ninth grade.

Alternative high schools that support at-risk and wounded students, with intentional efforts in the following five areas: Building Positive Relationships, Providing Supportive Safety Nets at School, Offering Counseling Services, 
Having a Food and Toiletry Pantry, Laundry Service and Bus Pass Bank and Focusing on Post-secondary Plans will support these scholars towards successfully earning their high school diplomas.

\section{Build Positive Relationships}

If an alternative high school focuses on building positive relationships with students who have struggled in other school settings and provides meaningful educational access and opportunity, the students will succeed. Research shows that the attitudes, skills, and beliefs of the school professionals who work in a school are the most important factors distinguishing schools where high levels of [academic] achievement are the norm for all students (Noguera, 2008). Research further supports that a positive, caring school professional could offer at-risk students substantial emotional and instructional support that could supplement the needs not met by a student's family or regular school program (McPartland \& Nettles, 1991). At-risk and wounded learners often lack long-lasting, stable relationships in their lives (Noguera, 2008). It is imperative for educators to build positive, healthy, and trusting relationships with at-risk and wounded students that they lead, teach, and develop daily.

\section{Provide Supportive Safety Nets at School}

Supportive safety nets may include daily monitoring of students' attendance rates, building positive and professional relationships between caring faculty and staff and students, online and traditional course offerings, rigorous and engaging instructional practices, weekly tutoring sessions, individual, substance abuse and group counseling meetings, cultural activities, free bus tokens/passes, career and college exposures and waivers for college application fees. Supportive safety nets maximize the at-risk student's ability to make the school the priority in his/her life. From having a mentor, to attending a flexible class schedule to receiving tutoring for a challenging class, supportive safety nets make attending school and thriving at it much more doable for at-risk and wounded learners.

\section{Offer Counseling Services}

It is critical to develop the whole child who has been identified as at-risk or wounded and attends an alternative high school. Staffing alternative high schools with mental health psychologists and/or substance abuse counselors will provide ongoing opportunities for students (and if appicable their familites) to address, and hopefully, correct any conceivably disruptive or potentially dangerous behaviors. Alternative high schools that foster safe, positive and caring educational environments must provide resources, such as social workers, psychologists, counselors, behavior intervention specialist, to address the counseling needs and services of at-risk and wounded students. Another viable option is to "refer students and families to (external) mental health and financial assistance services in a timely manner" to address behavioral concerns (DeAngelis, 2012).

\section{Have a Food and Toiletry Pantry, Laundry Service and Bus Pass Bank}

Quite often, at-risk and wounded students are their sole providers. Many are homeless, in foster care, living on their own or in transitional housing situations. When students arrive at school and know that they will receive a free meal, inclusive of "grab and go", non-perishable food, it is a beneficial factor in combating potentially, daily hunger issues. Providing toiletries like soap, toothpaste, shampoo and conditioner to cleanse themselves, laundry appliances inclusive of washers/dryers at the school building to clean dirty cloths and/or bus passes to get to and from school help support needy students - emotionally. They are no longer hungry, dirty or without transportation due to these small acts of kindness on the behalf of the alternative high school's food and toiletry pantry, laundry service and bus pass bank. If the school's budget is unable to cover the cost for non-perishable food, personal care toiletries and bus transportation tokens/passes, often times, these items may be donated by the district's homeless office (for identified students) or churches, non-profits or citizens in the local community. According to Gompert (2015), "Support from adults outside of school reduces the likelihood of young people leaving (dropping out) by 17 percent." 


\section{Focus on Post-secondary Plans}

An effective requirement for prospective graduating students, at alternative high schools, is a college or career plan for his or her future. It is an effective strategy for alternative high schools to require prospective graduating students to apply to and obtain viable post-secondary plans at a university, community college, enlist in one of the armed services, or find employment in the workforce. Alternative high schools may support each student's application to a university or community college by providing waivers for application fees. In addition, alternative high schools should sponsor a myriad of college visits and tours to expose students to the college experience. Sponsoring a Free Application for Federal Student Aid (FAFSA) Day to assist students and their families with completing documents for financial aid will help to secure possible funding to pay for the post-secondary plans. It is beneficial to administer to interested students the SAT/ACT, Armed Services Vocational Aptitude Battery (ASVAB) and Accuplacer (Community College) entrance exams to provide readiness information for university, community college, the military or career certification. Have representatives from the U.S. Army, Air Force, Navy, Coast Guards and Marines visit alternative high schools to talk with students about their options if he or she wants to serve in the military. For students interested in entering the workforce after graduation, offer students exposure to workbased programs like Lincoln College of Technology, Job Corp, Police or Fire Academy, and The Art Institute. It is paramount to have viable options for post-secondary plans that support student choices and interests. Ultimately, the goal is for alternative high schools to help at-risk and wounded students earn their diplomas and also have attainable post-secondary plans.

\section{CONCLUSION}

Students who graduate from alternative high schools, typically, have beaten the odds by earning their high school diplomas. Precisely, in a significant number of cases, students who attend alternative high schools are on the path to dropping out. These young people may have low-grade point averages, very little parental support, and lack plans for the future. It is critical that effective alternative high schools work daily to level the playing fields for these students, by positively turning their current life situations around, to ignite viable plans for their futures. These goals may be accomplished with wrap-around support services such as Building Positive Relationships, Providing Supportive Safety Nets at School, Offering Counseling Services, Having a Food and Toiletry Pantry, Laundry Service and Bus Pass Bank and Focusing on Post-secondary Plans in order to provide academic, developmental, social, and emotional support for these at-risk and wounded students to earn their high school diplomas.

\section{ACKNOWLEDGEMENTS}

This paper was originally presented at the 2019 Clute International Academic Conference on Education in Denver, Colorado.

\section{AUTHOR BIOGRAPHY}

Dr. Tammy Williams is currently the principal of Community-Based Classroom-An Alternative High School located in Bladensburg, MD. Dr. Williams describes her work as such: "I lead a successful alternative high school in Prince George's County Public Schools. My position is very rewarding because I work daily with many students facing some of life's most vulnerable situations. Importantly, I am pleased to help my students with their life challenges in order for them to earn their high school diplomas and make viable post-secondary plans. I often feel like a principal, who is also a social worker, primarily because my school services the educational, social, emotional, and developmental needs of this at-risk population in order for them to realize their true potential and attainable future. I make this comparison to a social worker because it is critical for my school to service the whole child with wrap-around support services." Importantly, this school has helped thousands of students move forward to lead productive, successful lives. 


\section{REFERENCES}

Anderson-Moore, K. (2006). Defining the term at-risk. Research to Results Trends. Publication \# 2006-12. October 2006. DeAngelis, T. (2012). Helping at-risk students success. American Psychological Association, February 2012, Vol, 43, No.2. Gomperts, J. (2015). Five ways we can help at-risk youth graduate from high school. Blog posted in Better Conversation. Hendershot, Reaching the Wounded Student, 2008.

McPartland, J., \& Nettles, S. (1991). Using community adults as advocates or mentors for at-risk middle school students: A twoyear evaluation of Project RAISE. Baltimore, MD: Center for Research on Effective Schooling for Disadvantaged Students, John Hopkins University.

Noguera, P. (2008). The trouble with black boys: ...And other reflections on race, equity, and the future of public education. San Francisco, CA: Jossey-Bass.

Slavin, R, \& Madden, N. (2004). Students at-risk of school failure: The problem of its dimensions. Johns Hopkins University, Center for Research on Elementary and Middle Schools. Boston, MA: Allyn \& Bacon.

StatisticsBrain.com. (2014). 